\title{
Comparison Between Interpretation of Viewers in Cultural and In Industrial Cities on The Myth: A Semiotic Analysis of The Indonesian Action Film The Raid 2: Berandal
}

\author{
Muhamad Gibraltar ${ }^{1,2}$ \\ ${ }^{1}$ Department of Communication, School of Law, Communication, and International Relations, Bekasi, Indonesia \\ ${ }^{2}$ President University, Bekasi, Indonesia
}

\section{Email Address:}

gibraltarmuhammad@gmail.com

\section{To cite this article:}

Muhamad Gibraltar. Comparison between Interpretation of Viewers in Cultural and in Industrial Cities on the Myth: A Semiotic Analysis of the Indonesian Action Film the Raid 2: Berandal. Humanities and Social Sciences. Vol. 2, No. 5, 2014, pp. 121-131. doi: 10.11648/j.hss.20140205.11

\begin{abstract}
In general, this proposal for qualitative research briefly reviews the structure of a research proposal from the beginning (Chapter 1) to the end (Chapter 3). It starts with the achievement made by The Raid 2: Berandal at the international level, which makes it worthy to become the analytical unit, and continues with the objective of this research: starting from digging and analyzing the myth contained in this film, to looking at the emerging interpretation on the myth when viewers watch the film. After that, the first research question is answered by using Roland Barthes' semiotic logical framework as the "Theoretical Container", which is integrated with other thoughts such as those of Arthur Asa Berger, Darmaprawira, Mas Dian, Barker, and Mark L. Knapp (first level analysis), continued with Susanne Langer's thought on Discursive Symbolism (second level analysis) in order to answer the second research question. As the result, in the first level of analysis, the data digging method used is literature-study, continued with in-depth interview.
\end{abstract}

Keywords: Qualitative, Semiotic, Signified, Signifier, Myth, Interpretation, “Theoretical Container”,

"Discursive Symbolism", Literature Study, and In-Depth Interview

\section{Background Information / Brief Information}

The achievement made by a movie is an indicator of the movie's quality in the eye of its viewers. This achievement may be in the form of profit made within a specific period in which the movie is shown in the cinemas, how long the movie can stay on top of the "Box Office" chart, the awards won by the movie in the international festivals, the achievement made by its cast in the international festivals, as well as the response and testimony of its viewers after watching the movie.

For example, such achievement was made by the movie titled: "Lucy", starred by Scarlett Johansson, which succeeded to take the first place at this week's Box Office, after generating an income of USD 44 million. "Lucy" succeeded to defeat high quality movies such as "Dawn of the Planet of the Apes", which dominated the box office for two consecutive weeks and succeeded in generating an income of 16.4 million US Dollar, and Hercules (starred by The Rock Dwayne Johnson) which came in second at the Box Office by generating a profit of 29 million US Dollar. Meanwhile, the horror movie "The Purge: Anarchy" came in fourth with an income of 9.9 million US Dollar. Subsequently, the Animation Movie: "Planes: Fire and Rescues" came in fifth with an achievement of 9.3 million US Dollar. (Singkirkan Hercules Film Lucy Rajai Box Office. Obtained From

http://www.jpnn.com/read/2014/07/28/248741/Singkirkan

$\%$ E2\%80\%98Hercules $\%$ E2\%80\%99,-Film-

\%E2\%80\%98Lucy\%E2\%80\%99-Rajai-Box-Office.

Accessed at August 18, 2014)

Moreover, Lucy itself is a science fiction movie about a woman named Lucy (played by Scarlett Johansson) who becomes a victim of abduction. She is abducted by a group of gangsters while partying in Taipei. Lucy's dazzling body is subsequently used for smuggling drug in a transaction. Lucy then undergoes an illegal surgery and the drug is sewn into her abdomen. Then, it turns out that this drug has 
unusual reaction to her DNA. All of a sudden, Lucy's body reacts abnormally and her brain becomes extremely sensitive. As the result, Lucy possesses a superpower since her brain can function maximally. After that, Lucy kills all the gangsters who abducted her. She also tries to find the answer to the strange occurrence which happened to her while fighting against the gangsters who are chasing her. (Singkirkan Hercules Film Lucy Rajai Box Office. Obtained From

http://www.jpnn.com/read/2014/07/28/248741/Singkirkan

$\%$ E2\%80\%98Hercules\%E2\%80\%99,-Film-

$\%$ E2\%80\%98Lucy\%E2\%80\%99-Rajai-Box-Office.

Accessed at August 18th, 2014)

Here, we can see that there is innovation attached in this movie. More concretely, it is Lucy who is able to maximize the strength of her brain by up to 100 percent in order to gain a superpower.

Furthermore, innovation in the film industry becomes a necessity if we want the film we produce to be successful in the market. One form of innovation which can be made is by introducing the viewers to terms which have never existed before in the community. It happened to "Divergent" which, out of the blue, introduced its viewers to terms like Candor (Honest), Erudite (Clever), Amity (Peaceful), Dauntless (Brave), and Abnegation (Selfless). This movie also causes its viewers to fantasize about whether they are "divergent" or having a mixed personality. (Ade Irwansyah. 2014. 7 Film Hollywood Terbaik dari Januari-Juni 2014. Obtained From http://showbiz.liputan6.com/read/2070809/7-filmhollywood-terbaik-dari-januari-juni-2014?p=7. Accessed at August 19th, 2014).

Other innovation is attached to a movie by changing a character or creature with bad nature into a good character, which may even play the role as the balancing force of the universe. The 2014 version of Godzilla presents a different form of Godzilla, which becomes a "good monster", because he is actually the one who will save the earth from the other two monsters. Here, Godzilla is considered as the nature's way to create balance. (Ade Irwansyah. 2014. 7 Film Hollywood Terbaik dari Januari-Juni 2014. Obtained From http://showbiz.liputan6.com/read/2070809/7-filmhollywood-terbaik-dari-januari-juni-2014? $\mathrm{p}=7$. Accessed at August $19^{\text {th }}, 2014$ ).

In fact, there are other movies which use innovation as their value added. One of them is Edge of Tomorrow starred by Tom Cruise. Initially, Tom Cruise (in the movie) is only a cowardly soldier, but at the end of the story, he manages to become a hero. Through this movie, we feel like playing a Video Game in which the character dies in the middle of the game, and must start all over again. The more often we play it; we become smarter and may eventually win at the end. Such excitement is offered by the 'Edge of Tomorrow'. (Ade Irwansyah. 2014. 7 Film Hollywood Terbaik dari Januari-Juni 2014. Obtained From http://showbiz.liputan6.com/read/2070809/7-filmhollywood-terbaik-dari-januari-juni-2014? $\mathrm{p}=7$. Accessed at
August 19th, 2014).

To this point, it can be concluded that innovation is necessary for a movie in order to improve the quality of the movie itself. Researches on movies, by performing academic discussions about movies, are extremely necessary to create a high-quality movie. However, it is impossible to create these innovations without scientific researches which discuss about this matter. Usually, the academicians in the film industry express their academic opinions on this matter.

In addition, several academic opinions have emerged, one of which is proposed by Charlotte Brunsdon. Through her book which is titled Screen Tastes: Soap Opera to Satellite Dishes, she said that "Pretty Woman" shows about how important the existence of money is in the contemporary American community. This movie is all about money, self-awareness of money, and appreciation of the value of money. Therefore, at the moment of first meeting between Edward and Vivian, Vivian proves herself as a tough negotiator when she says: "I never joke about money". (Brunsdon, 1997: page 96)

Nevertheless, Vivian is different from her friend Kit, and it can be seen on her behavior with regard to money. Despite working as a prostitute on Sunset Boulevard, Vivian shows that she is a good girl, with the potential to become a housewife. This is proven when Vivian warns her friend Kit by saying: "You spend the rental income to buy drugs". (Brunsdon, 1997: page 96)

Furthermore, through his book which is titled: Media, Communication, and Culture: A Global Approach, Lull successfully worked through a number of Hollywood movies such as Rambo II and Rambo III as well as Rocky $I V$. In his opinion, there are ideologies which show off the United States as a superpower country, which is unbeatable when fighting or combating at war in third world countries. This is shown when John Rambo is constructed as winning the fight in Vietnam and Afghanistan, as well as when Rocky Balboa, an American with strong muscles, beats a robotized Russian. (Lull, 1998: page 9)

Another review by James Lull is about White Nights, in which the Soviet military officers are stereotyped as clever but clumsy persons. In the last scene of this movie, the representatives of the Third World stand shoulder to shoulder to support the United States when Mikhail Barishnikov, a Soviet citizen who renounces his citizenship, and his American friend Gregory Hines flee from the Russians. It gives an impression that United States is extremely favorable among the people in the Third World countries, and this, in the opinion of James Lull, is considered as twisting the fact. Moreover, this kind of nationalism tends to blindly rage about. (Lull, 1998: page 9)

Specifically, James Lull uses the thought of "between two rocks". He attempted to create a balance between Emile Durkheim's Macro-Normative Collectivism and MicroCognitive Individualism. James Lull created a rationality in which ideology is able to hegemonize the viewers by 
affecting their conscience. (Lull, 1998: page 32-34)

However, the brief mentioning of James Lull's opinion does not directly mean that the researcher intends to use this analytical tool. It is merely an "intermezzo" on how a communication expert analyzes a movie. James Lull's thoughts are too broad to see and analyze The Raid 2: Berandal, considering that the martial arts scenes are extremely detailed, even per se. Subsequently, the researcher will give an opinion on how Roland Barthes analyzes a movie as an analytical unit.

Unlike James Lull, Roland Barthes tried to analyze the aspects of signs found in Julius Caesar. According to him, all characters in the movie wear a wig. Some of them are curly, some messy, some with tuft of hair, some greasy, all are combed, and there is no place for a bald head, although there were so many of them if we search in the Roman history. Those with only a little bit of hair are not free from the hairstyle rules, and the hairdresser for the main characters in this movie must still make the last curly wig which falls loose to the tip of the forehead of one Roman, in which its small size, overall, indicates the typical mix of sincerity, goodness, and victory. (Barthes, 2011: page 21)

What is associated with this continuously maintained wig? The quite simple one is the Roman characteristic. The curly hair in the forehead indoctrinates people with proof, and nobody will doubt that he/she is in the ancient Rome. And such certainty is permanent: the actor speaks, acts, disturbs himself, and argues on 'the question about universal values' thanks to the small flag attached on their forehead, without having to lose their credibility. Their general representation may even broaden into a sense of total security, which travels across the ocean and many centuries, and unites in the Yankee cup with a Hollywood extra serving. (Barthes, 2011: page 22)

In the category of capillary meaning, namely a sub-sign, in the form of a surprise in the dark night: Portia and Calpurnia, who are awakened in the dead of night, have uncombed hair (so that they look suspicious). The first one, Portia, the young one, expresses uncertainty with wavy curly hair: her unpreparedness, say, is at the first level. The second one, Calpurnia, which is middle-aged, shows an annoying weakness: one ponytail twists around her neck and hangs down on her right shoulder so that it displays a sign of traditional chaos, an asymmetry. However, these signs, at the same time, are excessive and ineffectual: they argue about a 'basic characteristic' of which they do not dare to fully acknowledge: they are not in a similar, congruent situation. (Barthes, 2011: page 22)

However, there is another sign in Julius Caesar: the faces of all cast members sweat continuously. Labors, soldiers, conspirators, all their rigid and tough characteristics are flowing (with Vaseline). And, silence really becomes an attribute with specific purpose. Like the Roman wig or ponytail in the night, sweat is a sign. But, a sign of what? Sign is a sense of morality. Everybody sweats because everybody is debating something within himself/ herself. Sweating means thinking. Throughout the movie, only Caesar does not sweat and keeps the gentle, calm and still faces. Caesar, certainly, Caesar, the object of the crime, does not sweat because he does not know, and does not think, so that he must keep the stiff, neatly arranged texture of a spectacle which remains isolated in the court room (in Barthes, 2011: page 24). The end result of Roland Barthes' semiotic thought is the myth. (Barthes, 2007: page 303)

To this point, a connecting line can be drawn that innovation in movies can contribute to the success of the movie itself. However, it is impossible to create such innovation without comprehensive academic studies on the movie.

Next, we return to the discussion about a movie's achievement. There are several Indonesian Movies which succeeded to make international achievement, just as the previously explained Box Office movies. One of them is the sequel or continuation of The Raid: Redemption, namely The Raid 2: Berandal. There are two main reasons why this movie is different from the local movies in general.

First, this movie succeeded in making achievement at the international level, among others in the United States. This movie can draw deep enthusiasm amid the American viewers, from commoners to celebrities.

In a number of literatures, it is stated that this movie can tranquilize its viewers from various countries through the fighting scenes which originate from the movements in pencak silat. In its third week in global Box Office, "The Raid Berandal" succeeded to take the $11^{\text {th }}$ position in the United States' Box Office chart, and succeeded in generating USD 956 thousand, defeating great movies such as Need for Speed, Non-Stop, and Arnold Schwarzenegger's The Sabotage which slipped to the $18^{\text {th }}$ position with USD 361 thousand. (Wow, the Raid 2 Masuk Peringkat 11 Box Office. Obtained From http://www.jpnn.com/read/ 2014/04/17/228957/Wow,-The-Raid-2-Masuk-Peringkat-

11-Box-Office-. Accessed at August $19^{\text {th }}, 2014$ )

It is also reported that a teenager in Jersey, the owner of YouTube account humpmasterflex22, was determined to drive one hour together with his family members from their home to New York, only to watch The Raid 2: Berandal. The teenager was even of the opinion that Iko Uwais deserves an Oscar as an actor and martial artist. (Wow, the Raid 2 Masuk Peringkat 11 Box Office. Obtained From http://www.jpnn.com/read/ 2014/04/17/228957/Wow,-TheRaid-2-Masuk-Peringkat-11-Box-Office-. Accessed at August $19^{\text {th }}, 2014$ )

In another new coverage, it is mentioned that foreign actors also enjoy The Raid 2: Berandal, such as Kevin Bacon who, through his personal twitter account, invited all his friends to watch the movie, and rent The Raid: Redemption. In his twitter account, Kevin Bacon expressed that "The Raid 2: Berandal really rocks". (Feby Ferdian. 2014. Giliran Pemain X-Men Puji the Raid 2. Obtained From http:// showbiz.liputan6.com/read/2034558/giliranpemain-x-men-puji-the-raid-2. Accessed at August $18^{\text {th }}$, 2014) 
Second, this movie brings pencak silat to global level. Director Gareth Evans did try to focus each scene in order to be rich with the nuances of pencak silat. Nevertheless, silat is not something new for Gareth Evans, which has previously directed Merantau, and, before that, has directed a documentary movie together with Christine Hakim. Evans admitted that he is inspired by the Hollywood movie legend, Martin Scorsese. And it seems that The Raid 2: Berandal borrows several cinematic techniques from director Quentin Tarantino, particularly in its choice of weapons. The examples are The Hammer Girl, the blind female criminal who uses hammer to kill; and The Baseball Bat Man, who uses baseball bat to kill his opponents. (Resty Woro Yuniar. 2014. The Raid Bawa Pencak Silat ke Layar Dunia. Obtained from http://indo.wsj.com/ posts/2014/04/21/the-raid-bawa-pencak-silat-ke-layardunia/. Accessed at August $18^{\text {th }}, 2014$ )

The pencak silat movements in the movie are exquisite because the 31-year Iko has learned pencak silat for more than 10 years. This martial art is a centuries-old martial art, which emphasizes the use of weapon and the deadly combination of elbow, foot, knee, hand, and sometimes the head. In his opinion, silat is a kind of martial arts which can be used to kill, but on the other hand, silat can also be transformed into people's attraction show. (Resty Woro Yuniar. 2014. The Raid Bawa Pencak Silat ke Layar Dunia. Obtained from http://indo.wsj.com/ posts/2014/04/21/theraid-bawa-pencak-silat-ke-layar-dunia/. Accessed at August $18^{\text {th }}, 2014$ )

The researcher believes that semiotics, particularly Roland Barthes' thought, can analyze this movie in depth. This is because this movie is full with fighting scenes, and it requires a detailed analytical tool to analyze it.

It does not stop there. The moral of this entire movie is that the good one will certainly win over evil. This is shown by how the individual action of Iko Uwais (playing as Rama) single-handedly beats the criminals in a building. The detail is as follows,

As a matter of fact, there has been no research which uses The Raid 2: Berandal as its analytical unit because this film is still new and has just been aired in 2014 .

However, the theoretical pattern previously used in this research is indeed an extension of the article written by the author for "Science $P G$ ", which uses as the analytical unit the Natural Fibers Extract Brand X Commercials Aired on Television in 2009-2011. The conclusion of this research is (Gibraltar, 2014: 105-106):

A. Two types of myths have emerged. In the first commercial, the emerging myth is that the Natural Extract Fiber is better than natural vegetables and fruits in preventing hemorrhoids. While in the second commercial, the emerging myth is that both products (the orange and grape flavored products) are better than natural vegetables and fruits in smoothing bowel movements.

B. After an in-depth interview with the public was conducted, it turned out that the first myth is not trusted by the public. However, the second myth is trusted by the public due to the presence of Ulfa Dwiyanti in this commercial.

The author intends to extend the logical framework previously used for analyzing two commercials for the same product, to use or extend it now for analyzing The Raid 2: Berandal.

Before closing the discussion in this sub-chapter, a connecting line can be drawn that there is relationship between the achievement made by movies which rule over the global "Box Office" chart and the academic studies conducted using movies as the analytical unit. Amid the domination of foreign Box Office Movies, there are a number of Indonesian movies which made an achievement, and even beat other western movies, and one of these Indonesian Movies is titled: The Raid 2: Berandal (the sequel of The Raid: Redemption), in which the value added of this movie is the fighting scenes between its international-class actors.

Finally, is it not time that the Indonesian People give a deep appreciation to their self-produced movies, by conducting in-depth research and analysis on this matter? If great names such as James Lull and Roland Barthes managed to give an academic touch on the cultural products they produce, why can't our own Indonesian people do that, in order to show Indonesian nationalism at academic area?

\section{The Objectives and Theoretical Frameworks}

In the previous discussion, it was mentioned that The Raid 2: Berandal has made international achievement by beating the performance of well-known movies in the global Box Office chart. In addition to that, Roland Barthes' semiotics is considered capable to serve as the analytical unit in this matter.

However, it has not finished yet, in which there is a sort of dynamics. Certainly, what is referred to as signified and signifier in this matter is those found in the denotation system level in Roland Barthes' semiotics.

The object to be studied is actually found in the connotation system level (connotative meaning of signified and signifier). In the first research question, the main logical framework used is Roland Barthes' semiotics. However, in the second question, an additional logical framework is used, namely: Susanne Langer's thought which may connect the difference between sign and symbol.

The main issue is Signifier and Signified, on both the denotation and connotation levels, considering that both cause different interpretation among viewers, particularly when sign changes into symbol.

Therefore, the issue in the present research is as follows: 


\section{A. What is the myth contained in The Raid 2: Berandal? \\ B. How do viewers interpret the myths contained in The Raid 2: Berandal?}

Therefore, the objective to be achieved in this research is as follows:

A. To dig and analyze the myth
contained in The Raid 2: Berandal.
B. To find out about viewers'
interpretation of the myth contained in The Raid
2: Berandal.

In order to answer the first research question, Roland Barthes' semiotic logical framework will be used. The description is as follows:

Roland Barthes' thought is described in the form of scheme. In brief, this is the "theoretical container" which will become the stepping stone of the analysis in the present research, while other theories (such as the theoretical development of Charon's symbolic interactionism, which later became more specific in Arthur Asa Berger's discussion on the concretization of signifier and signified, Barker's thought about the relationship between colors and moods, and Knapp) about nonverbal will become the "analytical knife" which fills the boxes in the scheme created by Roland Barthes, particularly box number 4: "Connotative Signified"; the box in which the interpretation of denotation system is conducted by the semiotic researcher:

Therefore, the starting point in this research is the "Second Level Signification", more specifically the "Connotative Signified".

The connecting line is that the whole sign-related logical framework is placed in the fourth column (connotative signified). As the result, what we can describe here is not only the social constructions hidden in The Raid 2: Berandal, but also various interpretations of signs in the form of colors, appearance, and nonverbal.

At the second level of analysis, there are a number of logical frameworks used to fill in the column number 4 (connotative signified). Subsequently, we will make it concrete with Mark L. Knapp's thought about the nonverbal concept, to the meaning of a color by Barker. The following is their respective narratives based on the matter.

Mark L. Knapp explained that the term nonverbal is usually used to describe all communication events other than said and written words. In this definition, nonverbal events and behavior are not really nonverbal in nature. The nonverbal field is an area which emphasizes the importance of phenomenon which is empirical, factual and concrete in nature, without speech and language. It means that the nonverbal field is related to concrete, real matters which can be proven through human senses. (Wibowo, 2011: 72)

The concretization of this thought is as expressed by Arthur Asa Berger in the following: (Sobur, 2009: 174-175)

Table 9.1. Concretizations of Signifier and Signified

\begin{tabular}{ll}
\hline \multicolumn{1}{c}{ Signifier } & \multicolumn{1}{c}{ Signified } \\
\hline 1. Long hair. & $\begin{array}{l}\text { Noncompliant with the culture } \\
\text { (especially for shabby hair). }\end{array}$ \\
2. Neat hair style. & Entrepreneurs. \\
3. Hair cut too short. & Gays and soldiers/both. \\
4. Brick brown. & Fond of sports, leisure activities. \\
5. Pale. & Intellectuals (sick people). \\
6. Levi's. & Casual clothes, the proletariat. \\
7. Designer jeans. & Respected, luxurious. \\
8. K. Mart's jeans. & Workers. \\
9. Three-piece suits. & Executives, entrepreneurs. \\
10. Suitcases. & Old-fashioned, traditional. \\
11. Diplomatic bags. & Typical successful entrepreneurs. \\
12. Handbags. & European style, Italian descents. \\
13. Backpacks. & Nomad. \\
14. Shopping bags. & Farmers. \\
15. Sandals. & Artists. \\
16. Winged. & Typical entrepreneurs. \\
17. Worker's boots. & Workers. \\
18. Nomad's boots. & Nature lovers, wanderers. \\
19. Pilot's glasses. & Middle class. \\
20. Chain glasses. & Geeks. \\
21. Dark/black glasses. & Typical street, crazy people. \\
22. Necktie with knot. & Educated people. \\
23. Thick necktie. & Old-fashioned people. \\
24. Rope necktie. & Provincial people, Westerners. \\
\hline
\end{tabular}

The last one is related with colors. Everybody certainly has a favorite color. And usually, this color affects their mood. The following is a description of mood associated with colors as stated by Barker (1954). (Sobur, 2009: 174175)

Table 9.2. Color-Associated Moods

\begin{tabular}{ll}
\hline \multicolumn{1}{c}{ Mood } & Color \\
\hline Exciting, stimulating & Red. \\
Safe, comfortable. & Blue. \\
Depressed, disturbed, confused. & Orange. \\
Soft, soothing. & Blue. \\
Protecting, defending. & Red, Brown, Black. \\
Very sad, heartbroken, unhappy. & Black, Brown. \\
Calm, peaceful, serene. & Blue, Green. \\
Dignified, noble. & Purple. \\
Fun, cheerful, happy. & Yellow. \\
Challenging, resisting, hostile. & Red, Orange. \\
Powerful, strong, excellent. & Black \\
\hline
\end{tabular}

The element of color is a fundamental element in the visualization of film. Colors play an important role in creating the meaning, particularly in terms of emotion and feeling. In art, the use of symbolic colors is an event considered important. According to Darmaprawira, several colors which have symbolic values in general are, among others: (Darmaprawira, 2002: 45-49)

Red: Of all the colors, red is the strongest and most 
attractive color, which is aggressive in nature and symbolizing the primitive. This color is associated with blood, anger, bravery, sex, danger, strength, virility, love, and happiness.

Purplish Red: The purplish red color has the characteristics of noble, glorious, rich, proud (arrogant), and impressive.

Purple: The characteristics of this color are cool, negative, backward, almost similar to blue but deeper and more solemn, and it has a gloomy and submissive character. This color symbolizes sorrow. It is contemplative, sacred, and a religious symbol.

Blue: It has cool, passive, calm and peaceful character; Goethe named this color as a dazzling, spiritual, monotheistic, and lonely color, which thinks about the past and future in the present. Blue is a perspective color, which draws us to solitude, chill, separation, and creates distance. Blue symbolizes the sacredness of hope and peace.

Green: It symbolizes contemplation, belief (religion) and eternity. It also expresses freshness, rawness, youth, immaturity, growth and hope, rebirth and fertility. The negative side of green is that it is disliked by children, associated with the color of diseases, hatred, venom, and jealousy.

Yellow: It symbolizes pleasure, agility and intellectuality, and also symbolizes the glory of love and deep understanding in interpersonal relationship.

White: It has positive, stimulating, bright, light and simple character, and it also symbolizes sacredness, innocence, honesty and purity.

Grey: It symbolizes calmness, politeness and simplicity. It also symbolizes intelligence, but it has a negative epitome of indecision. Its neutral character symbolizes a mediator in conflicts.

Black: It symbolizes darkness and the absence of light. It indicates dark force, the symbol of mystery and the color of the night. It is also often symbolized as the color of destruction or mistake. Black can also indicate a firm, robust, and formal attitude as well as a strong structure.

Furthermore, Mas Dian, a Feng Shui consultant, in his book "The Impact of Colors in Feng Shui" which was published in 2002, proposed that colors have characteristic that unequivocally affects a person's psychological condition and may provide various inspirations which stir the emotions. He also elaborated that the language of colors has different meanings, such as, among others (Dian, 2002: 1-2):

Pink: describing a feminine, soft, tender, beautiful and romantic character.

Red: symbolizing an energetic, mighty, dynamic, active and hot character.

Beige: symbolizing a soft, classic, exclusive, neutral, warm and sweet character.

Orange: describing a cheerful, popular, hard, bright, hot and fervent character.

Light Yellow: representing a cheerful and happy, bright, warm, soft, beautiful and sweet character.
Light Green: describing a fresh, happy, cheerful, and growing character.

Green: describing a classic, cool, worldly, exclusive and calm character.

Light Blue: symbolizing a calm, clean, cool, peaceful, gentle and relaxed character.

Blue: describing a classic, strong, confident, calm and professional character.

White: describing a calm, pure, clean, sacred, classic, sparkling and sorrowful character.

Black: symbolizing a classic, elegant, mystical, strong, hard, sexy and dramatic character.

Silver: describing an exclusive or expensive, elegant, classic and cool impression.

Gold: symbolizing an energetic, mighty, dynamic, active and hot impression.

The inclusion of these logical frameworks is quite important considering that there are various aspects to be analyzed in a film namely, in addition to words, also pictures and even the movements of each actor appearing in the movie. The concepts of nonverbal, kinesthetic, and association between moods and colors are extremely important to be included considering that The Raid 2: Berandal are not only displaying signs, but also various kinds of languages and grammars, movements of the actor, and a number of colors which send certain messages to the viewers who watch it.

As the result, it can be ensured that the thought of Darmaprawira and Mas Dian is extremely necessary as the analytical tool in this research.

In addition, the thought of Joel M. Charon about symbols is still too "Grandiose" and therefore needs to be specified.

In the concretization of this thought (for example, when looking at a suitcase), according to Joel M. Charon's concept as "Human Made Objects", the meaning of the suitcase is further diminished as something oldfashioned/traditional (Arthur Asa Berger). Considering that the suitcase has a black color, it gives the mood of powerful, strong, and of a very high quality (according to Barker's thought). Such diminution of concept can be manifested by learning about movements (kinesthetic), dialogues and colors.

The connecting line is that the important aspects to be studied in the research on movies or film are the aspects of color, dialogue and nonverbal.

Then, we continue with the second logical framework to answer the second research question. We move to the thought on "Discursive Symbolism" proposed by Susanne Langer. One of the important language theories is her "philosophy of the new key", which received various deep attention from many scholars who adhere to symbolism. According to Langer, the whole life of an animal is dominated by feelings, but human feelings are affected by conceptions, symbols, and languages. Susanne Langer said that "Symbols are not proxy of their objects but are vehicles for the conception of objects". In other words, a symbol is "an instrument of thought". (Littlejohn and Foss, 


\section{2: 61-62)}

Not only having the capacity in using symbols, but the community also has a need for those symbols, and the creation of symbols is an ongoing process, similar to the activities of eating and sleeping. Most of human behavior can be explained by the term of need for symbols. (Littlejohn and Foss, 2002: 62)

Then, how does a symbol work? Various types of symbols, including preposition, communicate a concept, general ideas, pattern or certain shapes. Concept is something whose meaning is shared between the communicators; however, each communicator also has a private image of the meaning of the symbol, which fills the details of a general image. This private image is referred to as a person's conception. (Littlejohn and Foss, 2002: 62)

A brief description of concept. Susanne Langer used the word "oscillation" as an example. A person may privately see it as the Swing of Pendulum, the shake of a skyscraper, the vibration or trill on a violin's string in accordance with the direction of the bow, the clenching of our teeth in a cold weather, etc. From all of these examples, we can draw a "logical form" as "a concept of oscillation", or "rhythmic motion to and fro. (Langer, 1967: 35-36)

In another literature, it is explained that a meaning, therefore, consists of an individual conception which is private in nature, and a general concept shared with other persons. For example, (Stephen L. Littlejohn and Karen Foss used this as an example), Vincent van Gogh's paintings which contain general symbols and private meanings. The private meanings of these paintings can be obtained by any person; they generally recognize these paintings. Such private meaning belongs to van Gogh himself and any person who has studied art. (Littlejohn \& Foss, 2002: 62)

The most important thing in Langer's thought is the three additional terms, namely signification, connotation, and denotation. Signification is the meaning of a sign, or a simple stimulus informing about the presence of one/more objects. Signification is a one-to-one relationship between a sign and an object or between the stop sign and the walk sign for pedestrians. (Littlejohn \& Foss, 2002: 63)

The logical framework placed in subchapter 2.1 In Order to Answer the First Research Question: Discussing about Sign will be used in this phase (signification), such as Roland Barthes' semiotic thought, Arthur Asa Berger (concretization of signifier and signified), Barker (colors and moods), Mark L. Knapp (nonverbal), Darmaprawira and Mas Dian (analysis of colors), particularly in digging the signifier, signified and social constructions hidden in the movie The Raid 2: Berandal.

In Susanne Langer's vocabulary, denotation is the relationship between a symbol and its object. For example, the denotation of the symbol "dog" in a person's mind is a brown-furred puppy sitting on the person's feet, even if the puppy does not really exist. On the contrary, connotation is a symbol which represents direct relationship between a symbol and conception. Connotation includes a person's personal feelings and associations attached to the symbol. For example, a puppy which stirs up a person's happy childhood memory, and so on. (Littlejohn \& Foss, 2002: 63)

The result of the communication process is referred to as interpretation. Interpretation is a process of forming a general idea based on various concrete experiences. The process leaves certain details in revealing objects, phenomena or situations in more general context/terms. Any continuing terms in this process will leave more details compared to the previously existing terms. In brief, Susanne Langer's thought can also be referred to by the term no presentational symbol. (Littlejohn \& Foss, 2002: 63)

Interpretation itself is conceptualized as an awareness of form, which contains matters of general analogous nature, (most importantly) separated from its content, and more correctly referred to as "concrete integuments". In addition, any interpretation must have the same patterns with one or two interpretations, like the inches in a ruler, steps on a ladder, continuation of Encyclopedia Britannica volumes, or interval between one US President and another US President. Interpretation (among others) consists of denotation and connotation. (Langer, 1967: 33)

Susanne Langer also explained that there is nothing difficult in understanding an abstract thought (making interpretation). This is not something abstract which can only be understood by a small number of people. As Lord Russell said: every person has "the forms of logics of some knowledge; and what must be done (by the person) is to make it more explicit, realized and familiar/easy to recognize". This is the form which will attract us, and not a medium in which the form is expressed. (Langer, 1967: 35)

In brief, interpretation referred to by Langer is the "interpretation of an abstract form". This is a process to see everything where everything comes from. For example, if we are interpreting the abstract concept of "rotation", we will think about the spin of a wheel, the movement of a body, the spin of a propeller, and so on. (Langer, 1967: 37)

This is how Susanne Langer's thought is explained, starting from the difference between sign and symbol, conception, to the difference between signification, denotation, and connotation; in which all of these will create certain interpretation if (the signal) reaches the viewers. This is what differentiates Susanne Langer's thought on "discursive symbolism" from other symbolic thoughts which are non-representational in nature.

The conclusion is that there is an "interaction" between signified, signifier and viewers' understanding, which will later affect viewers' interpretation of The Raid 2: Berandal, in which the signs create individual interpretation for the viewers who watch them. (Broden, 2002: 1-4)

This research uses the "triangulation of theory", which is practiced when the researcher uses various theoretical perspectives in performing the planning phase of a research, or when interpreting data. For example, the researcher plans to conduct research by using the concepts 
and assumptions of the conflict theory and at the same time the exchange theory (Neumann, 2006: 150). It is also the same with this research, in which the researcher uses the sign theory and the symbolic theory.

Before closing the discussion of this chapter two, the following is the theoretical scheme which rationalizes the whole logical framework above, both the one discussing about sign as well as the one discussing about symbol after the signal of the sign has been caught, and creates interpretation of signifier and signified for the viewers who watch it.

Before closing the discussion of this subchapter, the theoretical logical flow of this research (first phase) is as follows:

A. First Phase: Semiotic Analysis

Roland Barthes' semiotic thought in digging hidden signifier and signified as the "theoretical container", which includes: The Semiotic Analysis of Arthur Asa Berger (concretization of signifier and signified), Barker (colors and moods), Darmaprawira and Mas Dian (colors), and Knapp (Nonverbal)

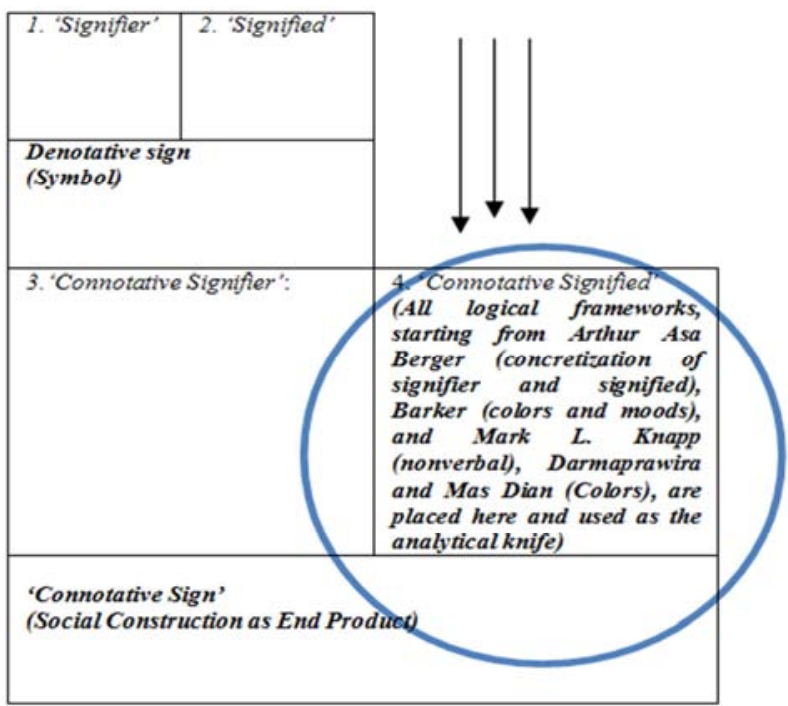

B. Second Phase: (Using Susanne Langer's thought on Discursive Symbolism): Discussing about Symbol (because the signs contained in the movie: The Raid 2: Berandal have been seen by viewers, and therefore create an interpretation in the mind of each of the viewers.

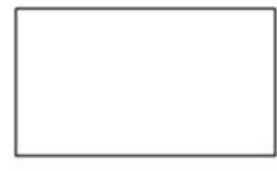

Television aired the Film: The Raid 2 Berandal
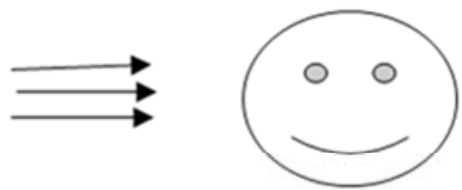

The viewers watched the action movie, and create interpretations in mind.

\section{Methodology}

This study uses the interpretive paradigm by combining two types of research methods, namely literature study and In-Depth Interview, using semi structured questions. In addition, the data analysis method used is the illustrative method, which sees everything as an empty glass filled in with water, and triangulated using the "negative sentence method" as a comparison in order to comprehensively obtain a qualitative explanation. (Gibraltar, 2012: 52-63)

The location and time of research took place in four big cities in the United States, considering that The Raid 2: Berandal has made an achievement in Uncle Sam's country. Further, the research will be held in 2 Cultural Cities of the United States, namely: New York and Los Angeles. This is because both cities are the centers of economy and industry, where the people are willing to spend money to go to the cinemas to watch movies. In addition, the largest film industry in the world, Hollywood, is located in Los Angeles. So is New York, where there are so many cultural movements originating and starting from this city, such as Harlem Renaissance and AfricanAmerican Renaissance; New York became the main stage of Jazz music in the 1940s, expressionism in the 1950s, and the home of hip hop, punk rock, and Beat Generation cultures. New York is an important center of music, movies, art, theater, and fine arts in the United States. The conclusion is that it can be ensured of that the people of these two cities (New York and Los Angeles) are "culturally literate".

Then, what about the Industrial Cities like Detroit which is the center of automotive industry, and Pittsburgh which has the largest steel industry in the United States? Although the cultural movement is not as lively as in Los Angeles and New York, it is very important to try to understand about viewers' interpretation in these two cities of this movie.

In this research, two types of methods for selecting informants will be used, which is certainly classified as "Non-Probability Sampling”.

The first one is "Theoretical Sampling", which is conceptualized as nonrandom sample in which researcher selects specific times, locations, or events to conduct observation in order to develop a social theory or to evaluate theoretical ideas (Neumann, 2006: 224). This method is used because the researcher has identified precisely the time, location, event, and even who are the informants who will be questioned related to the Case: The Raid 2: Berandal.

The objective of "theoretical sampling" is to find the manifestations of the construction of interest in order to elaborate and examine the construction along with its variations. (Patton, 2002: 243)

However, in order to improve the quality of this research, the "Snowball Sampling" method for selecting informants will also be used (it is also known as "chain referral sampling”), which is interpreted as nonrandom sample in 
which the researcher starts with one case, and based on information about the interrelationship of this case, other cases are identified, and the process will be repeated again and again. (Neumann, 2006: 223)

The objective of "snowball sampling" is to identify the cases of interest from people who knows which cases are rich of information, which can be used as a study, and for interviewing the right participants. (Patton, 2002: 243)

Procedurally, snowball sampling, both using the probability as well as non-probability techniques, is conducted in several phases. In the first phase, a number of persons with the same characteristic are identified and interviewed. These people are used as informants to identify other persons who may be selected into the sample. In the second phase, the researcher interviews the persons recommended in the first phase, who will subsequently give the names of persons who can be interviewed in the next phase. (Nurhidayat, 2002: 376)

The objective of the use of this method is to complement the "Theoretical Sampling" method, in order that the previously stipulated informants can give recommendation about new informants who can be asked about information related to the case of The Raid 2: Berandal.

The number of informants targeted is 10 persons, in which each City contributes 2 persons (one male and one female) who are selected using the snowball sampling. The remaining two persons are selected using the theoretical sampling with the specification that they must be movie experts: one expert from the university, and the other from the practitioners.

\section{How will the Research be Communicated to the Broader Community?}

This research can be communicated to the broader community, considering its wide scientific potential. Analyzed from this aspect, the result of this research can be communicated to the multidisciplinary scientific community other than communication sciences, starting from the literature and cultural studies (Roland Barthes' semiotic thought positioned as an elevator which may go up and down, until this movie brings the Indonesian pencak silat to the global level), business and economic sciences (considering that the result of this research can be used as reference on how Indonesian movies may penetrate the American and global movie market), Film Studies, to Moral and Ethical Studies (the ending of this movie shows how the good always wins over evil).

This research can also be extended to that domain considering that movies cannot be separated from scene. Scene is also closely related to semiotics, and can make semiotic approach (as used in this proposal) become more productive, to commensurate with the opinion made by Barry Shank: "Within a scene, far more semiotic information is produced than can be rationally parsed"
(Straw, 2005: page 412). Although the scene study rejects deciphering, this unifies the cultural energy which can create a collective identity (in this case the myth). (Straw, 2005: page 412)

\section{The Supervisory Provision as well as Specialist and Transferable Skills Training}

Actually, the author prepared this research proposal in order to register for Ph.D. in Communication Studies at the Department of Arts History and Communication Studies, Faculty of Arts, McGill University. At that time, the author contacted a person who is indeed a real "specialist" in the field of Film Studies, namely: Prof. Will Straw Ph.D.

Furthermore, the author has obtained the permission from Prof. Will Straw Ph.D. to change this proposal into a journal. In addition, analyzed from the aspect of "Transferable Skills Training”, Prof. Will Straw Ph.D. has approved to become my supervisor if I successfully obtain an Unconditional LOA (Letter of Acceptance) for this field of study. (Referring to the conversation between the author and Prof. Will Straw PhD. via email dated August 7 and August 17, 2014)

\section{Ethical Considerations}

In order to strengthen the structure of this research, the researcher has prepared Goodness criteria, which are criteria for assessing and interpreting data. For that purpose, the researcher selected goodness criteria. Further, in assessing "Goodness Criteria" of a qualitative research, there are a number of criteria to be fulfilled, namely: (This is not the complete list)

A. Completeness of Descriptions: or more precisely, how complete is the researcher's explanation of a social phenomenon, in accordance with the theoretical framework which has been developed.

B. Authenticity: as a certification or benchmark of quality of the researcher's presence in that setting.

C. Ecological Validity: Is the explanation of social phenomenon made by the researcher in accordance with the real condition on field?

D. Credibility: the bridge between researcher's interpretation and reality.

E. Plausibility: Seeing the consistency between the researcher's findings and the theories accepted and recognized by the scientific community.

(Seale et al, 2007: 377)

Then, what has been made by this study in implementing or achieving these "Goodness Criteria"? The following are several things conducted by the researcher:

A. This research will explain to the details at the semiotic analysis level about interpretations of signs contained in The Raid 2: Berandal. Not only using the thought of Roland Barthes (considering that this is not sufficient), 
but also using other thoughts such as the thoughts of Barker, Mark L. Knapp, Arthur Asa Berger, Darmaprawira and Mas Dian. This is because a study about movie is a complex study, not only involving content, expression, and representation, but also movements (silat movements), colors, facial expressions, sounds, etc. (Completeness of Descriptions)

B. Researcher presents the complete verbatim quote of the five informants in the attachment to this research, as the proof of the researcher's presence at the research location. (Authenticity)

C. The real condition happening in the community must be clearly described, that is why the researcher uses Susanne Langer's thought on "Discursive Symbolism", which attempts to establish a connection between sign and symbol. (Ecological Validity)

D. It is also the case with "Credibility" in which Susanne Langer's thought will play the role of bridge between sign and symbol, and at the same time the connector between reality and the researcher's interpretation.

E. Finally, the researcher will use Roland Barthes' logical framework and other logical framework in order that the already developed theoretical frameworks do not go anywhere, but are locked in the thought. (Plausibility)

\section{Summary and Conclusions}

This research is quite unique, considering its analytical unit, namely an Indonesian Movie which scored a phenomenal achievement in the international Box Office, particularly the United States. Because of this, the author wants to conduct a more in-depth research about The Raid 2: Berandal in order to dig the myth hidden therein (first phase analysis), and at the same time to find out about viewers' interpretation of the developed myth (second phase analysis).

In order to answer the first research question, Roland Barthes' semiotic analysis is used, which is positioned as the "Theoretical Container" to accommodate other thoughts such as Arthur Asa Berger's concretization of signifier and signified, Local Theory of Colors from Darmaprawira and Mas Dian, Barker's thought (colors and moods), and Mark L. Knapp (Nonverbal). In brief, the first phase analysis is purely a literature study.

Further, Susanne Langer's thought on Discursive Symbolism is used to answer the second research question, in order to see how the viewers interpret the myth which has emerged in the movie. To support it, in-depth interview is used in order to dig viewers' interpretation. It does not stop there, but the triangulation between "the Negative Sentence Method" and the Illustrative Method is absolutely necessary in order to increase the validity of the obtained data. Another triangulation used is a combination of the Theoretical Sampling method and Snow Ball Sampling.

Concretely speaking, 8 out of 10 informants are selected by using snow ball sampling in which two residents from each city will be interviewed, one male and one female. The remaining 2 persons, who will be stipulated using theoretical sampling, are movie experts, in which one of them is a movie expert from the university, and the other is movie practitioner.

This research will be located in 4 different cities in the United States, for example: Los Angeles and New York (Cultural Cities), Pittsburg and Detroit (Industrial Cities).

Furthermore, this research proposal is created for the purpose of registering for Ph.D. in Communication Studies at Department of Arts History and Communication Studies, Faculty of Arts, McGill University. Prof. Will Straw Ph.D. has approved to supervise the author (if accepted in the Study Program), and at the same time has approved that the author can transform this research proposal to be issued in the form of scientific journal.

In terms of research ethics, this research will attempt to meet the maximally stipulated Goodness Criteria. It starts with factors such as Completeness of Description (creating an explanation detailed to the silat movements), Authenticity (creating the complete verbatim quotes of the ten informants), Ecological Validity (assessing through indepth interview the real interpretation of the informants within the ecology of 4 different cities), Credibility (connecting between sign and symbol in which an in-depth interview will identify viewers' interpretation), and Plausibility (the use of semiotic thoughts of Roland Barthes and Susanne Langer to prevent the explanation in this research from going off topic).

In conclusion, it is the precise time to create the academic foundations that can be useful to support the development of Indonesian movies in the future, so that they can compete with foreign films rateably.

\section{References}

[1] Adityawan, Arief. (2008). Propaganda Pemimpin Politik Orde Baru (Propaganda of the New Order's Political Leader). Jakarta: LP3ES.

[2] Baxter, Leslie and Babbie. (2004). the Basics of Communication Research. Canada: THOMSON WADSWORTH.

[3] Brunsdon, Charlotte. (1997) . Screen Tastes: Soap Opera to Satellite Dishes. London \& New York: Rout ledge.

[4] Bruzzi, Stella. (1997). Undressing Cinema: Clothing and Identity in the Movies. London \& New York: Rout ledge.

[5] Charon, Joel M. (2007). Symbolic Interactionism, an Introduction, an Interpretation, Integration: Ninth Edition. New Jersey: Pearson.

[6] Correspondence between Muhamad Gibraltar and Prof. Will Straw Ph.D. via email, dated August 07 and August 17, 2014.

[7] Dian, Mas. (2002). Pengaruh Warna dalam Feng Shui (The Impact of Colors in Feng Shui). Jakarta: PT. Elex Media Komputindo. 
[8] Ferdian, Feby. (2014). Giliran Pemain X-Men Puji the Raid 2. Obtained From http://showbiz.liputan6.com/read/2034558/giliran-pemain-Xmen-puji-the-raid-2. Accessed at August $18^{\text {th }}, 2014$.

[9] Griffin. E.M. (2006). A First Look at Communication Theory: Sixth Edition. Singapore: McGraw Hill, Inc.

[10] Gibraltar, Muhamad. (2014). Viewers Interpretation of Myth: A Semiotic Analysis of Natural Extract Fiber Brand X Commercials Aired on Televisions from 2009-2011. Inside Science PG Journal of Humanities and Social Sciences, page 96-107.

[11] Gibraltar, Muhamad (Theses). (2012). Interpretasi Pemirsa Terhadap Penanda dan Petanda (Analisis Semiotika Iklan Sari Serat Alami Merek X di Televisi antara Tahun 20092011). Jakarta: Magister Ilmu Komunikasi UI.

[12] Irwansyah, Ade. 2014. 7 Film Hollywood Terbaik dari Januari-Juni 2014. Obtained From http://showbiz.liputan6.com/read/2070809/7-filmhollywood-terbaik-dari-januari-juni-2014?p=7. Accessed at August $19^{\text {th }}, 2014$

[13] Langer, Susanne K. (1967). An Introduction to Symbolic Logic: Third Revised Edition. New York: Dover Publications, INC.

[14] Lull, James. (1998). Media, Komunikasi, dan Kebudayaan: Suatu Pendekatan Global (Media, Communication, and Culture: A Global Approach). Jakarta: Yayasan Obor Indonesia.

[15] Lindlof, Thomas $\mathrm{R}$ dan Taylor. (2002). Qualitative Communication Research Methods (Fourth Edition). London and New Delhi: Sage Publications.

[16] Littlejohn, Stephen and Foss. (2007). Theories of Human Communication: Seventh Edition. New Mexico: THOMSON

[17] Miller, Katherine. (2005). Communication Theories: Perspectives, Processes, and Contexts (Second Edition). Singapore: McGraw Hill.

[18] Minichiello, Victor et al. (1995). In-Depth Interviewing: Second Edition. Malaysia: Longman Australia Pty Ltd.

[19] Neuman, W. Lawrance. (2006). Social Research Methods:
Qualitative and Quantitative Approaches (Sixth Edition). United States of America: Pearson International Edition.

[20] Nurhidayat, Dedy. (2002). Kumpulan Bahan Kuliah Metode Penelitian Komunikasi 1: Program Studi Ilmu Komunikasi (Compilation of Lecture Materials of Communication Research Method 1: Communication Sciences Study Program). Jakarta: University of Indonesia.

[21] Patton, Michael Quinn. (2002). Qualitative Research's Evaluation Methods. London: Sage Publications.

[22] Singkirkan Hercules Film Lucy Rajai Box Office. Obtained From

http://www.jpnn.com/read/2014/07/28/248741/Singkirkan\% E2\%80\%98Hercules\%E2\%80\%99,-Film-

$\%$ E2\%80\%98Lucy\%E2\%80\%99-Rajai-Box-Office. Accessed at August 18, 2014

[23] Sobur, Alex. (2009). Semiotika Komunikasi (Semiotics of Communication). Bandung: Rosdakarya.

[24] Soekanto, Soerjono. (1993). Kamus Sosiologi: Edisi Baru (Dictionary of Sociology: New Edition). Jakarta: PT. Raja Grafindo Persada.

[25] Soeprapto M.S, Riyadi. (2002). Interaksionisme Simbolik: Perspektif Sosiologi Modern (Symbolic Interactionism: Perspective of Modern Sociology). Yogyakarta: AVERROES PRESS.

[26] Straw, Will. (2005). Cultural Scenes. Inside Loisir et société/Society and Leisure, vol. 27, no. 2 (autumn, 2004), pp. 411-422.Quebec: Presse de l'Universite' du Quebec.

[27] Sulasmi, Darmaprawira. (2002). Warna: Teori dan Kreativitas Penggunaannya: Edisi Kedua (Colors: Theory and Creativity in Using Them: Second Edition). Bandung: Bandung Institute of Technology.

[28] Wibowo, Indiwan Seto Wahyu. (2011). Semiotika Komunikasi: Aplikasi Praktis bagi Penelitian dan Skripsi Komunikasi (Semiotics of Communication: Practical Application for Communication Research and Bachelor Level Thesis). Jakarta: Mitra Wacana Media.

[29] Woro Yuniar, Resty. 2014. The Raid Bawa Pencak Silat ke Layar Dunia. Obtained from http://indo.wsj.com/ posts/2014/04/21/the-raid-bawa-pencak-silat-ke-layardunia/. Accessed at August $18^{\text {th }}, 2014$ 